\title{
Dampak Prosedur dan Reviu Inspektorat Terhadap Peningkatan Akuntabilitas LKPD Provinsi Banten
}

\author{
Jessi Chintiaranita Listira dan Septian Bayu Kristanto
}

\author{
Universitas Kristen Krida Wacana, Jl. Tanjung Duren Raya No.4 Jakarta Barat, 11470, DKI Jakarta, Indonesia
}

\author{
A R T I C L E I N F O \\ Article history: \\ Received 20 April 2018 \\ Revised 22 Mei 2018 \\ Accepted 29 Juni 2018 \\ Keywords: \\ Procedure; Review; Accountability, \\ Local Government, Financial State- \\ ments, Audit Opinion.
}

\begin{abstract}
A B S T R A C T
This research wants to analyze the effect of procedure and review inspectorate towards accountability of Local Government Financial Statement (LGFS) Banten Province. Researchers interested in extreme changes of audit opinion on LGFS Banten in period 2013 to 2016. The change from disclaimer opinion to qualified opinion, and then unqualified opinions in short period are crucial. The analyze result of LGFS in 2016 shows that the review procedures from The Audit Board of Republic Indonesia (BPK RI) are reasonably assured. Those reviews are effecting the increasing of accountability of LGFS in period 2015 and 2016. This result means Banten Province has been covered their LGFS quality. The suggestion in this research is to optimize the role of Government Internal Supervisory Apparatus (APIP) to maintain the quality and accountability of LGFS in the future.
\end{abstract}

\begin{abstract}
A B S T R A K
Penelitian ini bertujuan untuk menganalisa dampak prosedur dan reviu inspektorat terhadap peningkatan akuntabilitas Laporan Keuangan Pemerintah Daerah (LKPD) Provinsi Banten. Peneliti tertarik dengan perubahan ekstrim dari opini audit di LKPD Provinsi Banten pada tahun 2013 ke 2016. Perubahaan dari opini disclaimer ke qualified, daan kemudian menjadi unqualified dalam periode yang cukup singkat sangat krusial. Hasil analisis terhadap LKPD TA 2016 menunjukkan bahwa prosedur reviu yang dilakukan oleh BPK RI sudah sesuai dengan prosedur. Dampak dari reviu tersebut juga mengakibatkan peningkatan kualitas akuntabilitas LKPD Provinsi banten di TA 2015 dan 2016. Hal ini menujukkan bahwa Provinsi Banten sudah mulai memperbaiki akuntabilitas Pelaporan Keuangan Daerahnya. Hasil penelitian ini juga memberikan saran untuk memaksimalkan peran APIP sehingga kualitas dan akuntabilitas LKPD tetap terjaga di masa depan.
\end{abstract}

\section{LATAR BELAKANG PENELITIAN}

Pada tahun 1999 Indonesia melakukan gerakan reformasi dibidang Pemerintah Daerah (Pemda). Gerakan ini ditandai dengan dikeluarkannya UU No.22 Tahun 1999 (revisi menjadi UU No.32 Tahun 2004) oleh Pemerintah mengenai pembagian dan pembentukan daerah dari Negara Kesatuan Republik Indonesia yang bersifat otonom dan menerapkan asas desentralisasi. Berikutnya, UU No.25 Tahun 1999 (revisi menjadi UU No.33 Tahun 2004) mengenai perimbangan keuangan antara Pemerintah Pusat dan Pemerintah Daerah. Selain itu, dalam rangka reformasi pengelolaan Keuangan Negara, Pemerintah juga mengeluarkan instrumen yaitu UU No.17 Tahun 2003 mengenai Keuangan Negara, UU No.1 Tahun 2004 mengenai Perbendaharaan Negara, dan UU No.15 Tahun 2004 mengenai Pemeriksaan Pengelolaan dan Tanggung jawab Keuangan Negara.
Peraturan perundang-undangan tentang reformasi keuangan negara, selanjutnya akan menjadi pedoman bagi Pemerintah Pusat dan Pemerintah Daerah dalam melaksanakan tata kelola Keuangan Negara daan Daerah melalui Anggaraan Penerimaan Belanja Negara (APBN) dan Anggaran Penerimaan dan Belanja Daerah (APBD). Pelaksanaan APBD tersebut akan menghasilkan Laporan Keuangan Pemerintah Daerah (LKPD) untuk selanjutnya diserahkan kepada Badan Pemeriksa Keuangan Republik Indonesia (BPK RI) agar dilakukan Pemeriksaan Keuangan yang menghasilkan opini audit sebelum dipertanggungjawabkan kepada Dewan Perwakilan Rakyat Daerah (DPRD). Berdasarkan data pemeriksaan keuangan BPK RI Perwakilan Provinsi Banten, untuk tahun anggaran 2013 atas kepatuhan terhadap undang-undang, provinsi Banten mendapatkan opini Tidak Memberikan 
Pendapat (TMP) atau "Disclaimer" (surat nomor 17/LHP/XVIII.SRG/05/2014). Begitu pula dengan laporan hasil pemeriksaan atas Sistem Pengendalian Intern yang tercantum di dalam surat keterangan nomor 17a/LHP/XVIII.SRG/05/2014. Selain itu, pada tahun anggaran 2014, BPK RI Perwakilan Provinsi Banten kembali menolak untuk memberikan opini atas LKPD Provinsi Banten tahun 2014 sesuai dengan laporan hasil pemeriksaan atas Sistem Pengendalian Internal dan atas kepatuhan terhadap ketentuan peraturan perundang-undangan yang telah disajikan (surat laporan nomor 15a/LHP/XVIILSRG/05/2015 dan nomor 15b/LHP/XVIII.SRG/05/2015).

Di tahun anggaran 2015, BPK RI menunjukkan peningkatan hasil pemeriksaan terkait LKPD Provinsi Banten dari tahun anggaran sebelumnya dengan memberikan pendapat Wajar Dengan Pengecualian (WDP) atau qualified opinion berdasarkan laporan hasil pemeriksaan atas Sistem Pengendalian Intern dan kepatuhan terhadap ketentuan peraturan perundang-undangan yang telah disajikan (surat laporan nomor 10b/LHP/XVIII.SRG/05/2016 dan nomor 10c/LHP/XVIII.SRG/05/2016). Satu tahun anggaran kemudian, LKPD provinsi Banten untuk tahun anggaran 2016 menunjukan prospek yang begitu baik dengan diraihnya opini Wajar Tanpa Pengecualian (WTP) atau unqualified opinion dari BPK perwakilan provinsi Banten yang didasarkan juga atas dilakukannya pemeriksaan terhadap sistem pengendalian intern dan kepatuhan terhadap peraturan perundang-undangan yang telah disajikan (laporan nomor 19b/LHP/XVIII.SRG/05/2017 19c/LHP/XVIII.SRG/05/2017). dan

Hasil comparing opini BPK diatas merupakan salah satu tolok ukur dasar yang digunakan untuk melakukan penelitian apakah pengelolaan keuangan negara yang dilakukan pemerintah provinsi Banten sudah berjalan transparan dan akuntabel atau tidak. Hal tersebut menjadi perhatian bagi peneliti sehingga tertarik untuk melakukan analisis lebih lanjut mengenai prosedur dan dampak dari reviu yang telah dilakukan Inspektorat Provinsi Banten terhadap kualitas LKPD Provinsi Banten terkait dengan Opini yang telah diberikan oleh BPK RI. Dari latar belakang permasalahan yang telah diuraikan tersebut, maka permasalahan yang akan dibahas dalam penelitian ini adalah: (1) Bagaimana prosedur perencanaan, pelaksanaan serta pelaporan reviu inspektorat terhadap peningkatan akuntabilitas laporan keuangan pemerintah daerah provinsi Banten? dan
(2) Bagaimana dampak reviu inspektorat terhadap peningkatan akuntabilitas laporan keuangan pemerintah daerah provinsi Banten?

Penelitian ini bertujuan untuk mengetahui prosedur reviu laporan keuangan pemerintah daerah oleh inspektorat provinsi Banten pada setiap tahap perencanaan, pelaksanaan dan pelaporan, dan mengetahui dampak dari reviu inspektorat terhadap peningkatan akuntabilitas LKPD Provinsi Banten. Penelitian ini juga bermanfaat untuk mendukung stewardship theory, terkait dengan pelaksanaan reviu oleh inspektorat. Manfaat lain, penelitian ini dapat memberikan kontribusi dasar pertimbangan bagi stakeholders terutama pihak yang terkait dalam melakukan reviu terhadap LKPD.

\section{TINJAUAN PUSTAKA}

\subsection{Kualitas dan Akuntabilitas LKPD}

Kualitas merupakan segala sesuatu yang diartikan sebagai kesesuaian dengan standar, diukur berbasis ketidaksesuaian, serta dicapai melalui pemeriksaan. Menurut PP No.71 (2010), laporan keuangan yang berkualitas memiliki karakteristik relevan, andal, dapat dibandingkan serta dapat dipahami. Kualitas LKPD di nilai oleh badan pemeriksa keuangan (BPK) setiap tahun dengan cara diaudit. Hasil dari pengauditan oleh BPK tersebut dinyatakan dalam 5 (lima) jenis opini yaitu wajar tanpa pengecualian (WTP/Unqualified Opinon), wajar tanpa pengecualian dengan paragraf penjelas (WTP-DPP/Unqualified Opinion Report with Explanatory Pharagraph), wajar dengan pengecualian (WDP/Qualified Opinion), tidak wajar (TW/Adverse) dan tidak menyatakan pendapat (TMP/Disclaimer). Representasi kewajaran dituangkan dalam bentuk opini dengan mempertimbangkan kriteria kesesuaian laporan keuangan dengan standar akuntansi pemerintahan (SAP), kecukupan pengungkapan, kepatuhan terhadap peraturan perundang-undangan, dan efektivitas pengendalian internal (Indrisih, 2014)

Fenomena yang saat ini sedang berkembang dalam lingkup sektor publik di Indonesia adalah menguatnya tuntutan dari arus reformasi keuangan daerah mengenai akuntabilitas sektor publik dengan harapan tercapainya suatu sistem akuntansi yang baik (good accounting system) yang dapat mendukung akuntabilitas atas lembagalembaga publik, baik di pusat maupun daerah. Menurut Peraturan Pemerintah No.71 tahun 2010 tentang Standar Akuntansi Pemerintah, Akuntabilitas mempertanggungjawabkan pengelolaan keuangan dan sumber daya serta 
pelaksanaan kebijakan yang dipercayakan kepada entitas pelaporan dalam mencapai tujuan yang telah ditetapkan secara periodik. Akuntabilitas keuangan merupakan alat pertanggungjawaban lembaga-lembaga publik dalam menggunakan dana publik (public money) secara ekonomis, efisien, efektif, tidak ada pemborosan dan kebocoran dana, serta korupsi. Dalam konteks organisasi sektor publik, keputusan yang diambil harus memenuhi prinsip akuntabilitas publik terutama terkait dengan akuntabilitas kebijakan. Oleh karena itu, kualitas informasi berupa keakuratan, transparansi, ketepatan waktu, validitas, relevansi dan keandalan informasi keuangan akan sangat mempengaruhi kualitas keputusan dan akuntabilitas laporan keuangan yang dihasilkan.

\subsection{Prosedur dan Reviu Inspektorat}

Prosedur reviu yang wajib dilakukan dalam melaksanakan reviu sebuah laporan keuangan yaitu penelusuran angka, prosedur analitis dan permintaan keterangan. Penelusuran angka dilakukan untuk mendapatkan keyakinan bahwa penyajian angka dalam Laporan Keuangan (LK) benar dan akurat dengan menelusuri angka-angka tersebut ke buku atau catatan-catatan yang digunakan (Widyarini dan Ratnadi, 2016).

Apabila saat melakukan penelusuran angka ditemukan permasalahan yang harus ditindaklanjuti dengan verifikasi maka tahap meminta keterangan kepada Pejabat Pengelola Keuangan Daerah (PPKD) atau Kepala Satuan Kerja Perangkat Daerah (SKPD) perlu dilakukan untuk mendapatkan sebuah konfirmasi atas informasi yang menjadi permasalahan tersebut. Untuk akun dan kejadian yang tidak biasa (tidak sesuai SAP) dapat dilakukan pengidentifikasian dengan prosedur analitis seperti penilaian kewajaran saldo dan rincian laporan keuangan serta kesesuaian dan keterkaitannya antar komponen laporan keuangan. Ketika inspektorat menyusun prosedur analitis, maka harus dipertimbangkan juga reviu atas SPI supaya reviu kesesuaian terhadap SAP menjadi terarah pada akun-akun yang pengendaliannya lemah dan komponen laporan keuangan yang tersaji. Selain itu, kejadian luar biasa dan perubahan kebijakan akuntansi perlu dipertimbangkan juga dalam melakukan penyesuaian.

Kualitas reviu merupakan kemampuan aparatur pengawas intern pemerintah (APIP) untuk mengidentifikasi dan melaporkan pelanggaran dalam sistem akuntansi dengan pengetahuan dan keahlian dari pejabat APIP.
Kualitas reviu akan menjamin tercapainya tujuan reviu yakni memberikan keyakinan terbatas bahwa LKPD disusun berdasarkan SPI dan disajikan sesuai SAP (Widyarini dan Ratnadi, 2016). APIP merupakan pengawas intern kementerian/lembaga ataupun pemerintah daerah yang terdiri dari Inspektorat Jenderal Kementerian, Unit Pengawasan Lembaga Pemerintah Non Kementerian, seperti: Badan Pemeriksa Keuangan dan Pembangunan (BPKP), Inspektorat Provinsi, serta Inspektorat Kabupaten/Kota. Menurut pasal 58 UU No.1 Tahun 2004 tentang perbendaharaan negara APIP dibentuk dengan maksud untuk meningkatkan kinerja, transparansi, dan akuntabilitas pengelolaan keuangan negara. Pasal 48 ayat (2) PP No.60 Tahun 2008 menyebutkan, APIP melakukan pengawasan intern melalui: audit; reviu; evaluasi; pemantauan; dan kegiatan pengawasan lainnya. Kemudian, Pasal 16 ayat (2) PP No.12 Tahun 2017 tentang Pembinaan dan Pengawasan Penyelenggaraan Pemerintah Daerah menegaskan bahwa APIP melaksanakan pengawasan penyelenggaraan pemerintahan daerah berdasarkan prinsip-prinsip profesional, independen, objektif, serta berorientasi pada perbaikan dan peringatan dini.

\section{METODE PENELITIAN}

\subsection{Jenis Dan Sumber Data}

Jenis data yang digunakan oleh penulis dalam penelitian ini adalah data kualitatif. Data kualitatif diperoleh melalui teknik pengumpulan data yaitu berupa analisis dokumen. Sumber data yang dipakai dalam penelitian ini adalah data sekunder. Data yang dimaksud adalah buku-buku/literaturliteratur yang mempunyai hubungan erat dengan masalah penelitian; profil, struktural pejabat, visi dan misi inspektorat Banten; Laporan Hasil Reviu (LHR) LKPD Provinsi Banten; hasil prosedur analitis LKPD Provinsi Banten diperoleh dari inspektorat Provinsi Banten dan Laporan Hasil Pemeriksaan (LHP) BPK perwakilan Banten atas LKPD Provinsi Banten yang diperoleh dari pusat informasi dan komunikasi BPK RI.

\subsection{Metode Analisa Data}

Penelitian ini menggunakan metode analisa data berupa analisis deskriptif kualitatif seperti analisa dokumen dari sumber penelitian dan analisa peraturan yang ada. Penelitian (deskriptif) kualitatif adalah penelitian yang dilakukan dalam setting tertentu yang ada dalam kehidupan riil (alamiah) dengan maksud menginvestigasi dan memahami fenomena prosedur reviu secara bertahap 
dimulai dari perencanaan, pelaksanaan dan pelaporan. Melalui penelitian ini diharapkan agar mendapatkan informasi mengenai prosedur dan dampak dari reviu atas LKPD oleh Inspektorat terhadap kualitas akuntabilitas LKPD pada Pemerintah Daerah provinsi Banten.

\section{ANALISIS DAN PEMBAHASAN}

Untuk membatasi kajian permasalahan yang dibahas, penelitian kualitatif ini berfokus pada laporan hasil reviu LKPD provinsi Banten tahun anggaran 2016 yang telah dilakukan oleh inspektorat provinsi Banten mengenai penerimaan opini WTP atas laporan keuangan pemerintah daerah yang diterima oleh pemerintah Provinsi Banten.

\subsection{Reviu LKPD Tahun Anggaran 2016}

\subsubsection{Perencanaan}

Inspektorat pemerintah provinsi Banten telah melakukan proses perencanaan reviu LKPD Provinsi Banten tahun anggaran 2016. Dalam melaksanakan proses perencanaan reviu tersebut sudah cukup terealisasi dengan baik. Pertama, Pemahaman atas entitas yang direviu. Proses pemahaman atas entitas telah dilaksanakan antara lain dengan pengumpulan berita atau informasi terkait dengan pengelolaan keuangan pemerintah Provinsi Banten selama tahun anggaran 2016. Selain itu inspektorat yang merupakan salah satu Satuan Kerja Perangkat Daerah (SKPD) di lingkungan Pemerintah Daerah Provinsi Banten, mengakibatkan baik secara langsung maupun tidak langsung telah dapat mengidentifikasi informasi-informasi pelaksanaan keuangan daerah selama tahun anggaran 2016. Pelaksanaan pemahaman atas entitas tersebut dapat dilaksanakan secara optimal meninjau dari (a) Pemerintah Provinsi Banten selama tahun anggaran 2016 "sudah memiliki Peraturan Gubernur Banten tentang Sistem dan Prosedur Pengelolaan Keuangan Daerah Provinsi Banten" yang disajikan di dalam Pergub No. 3 tahun 2015. Oleh karena itu, hal ini berdampak pada pemahaman entitas dalam pelaksanaan dan analisa pengelolaan keuangan yang memadai. dan (b) Pemerintah Provinsi Banten selama tahun anggaran 2016 "sudah menggunakan perubahan kedua (terbaru) atas Peraturan Gubernur Banten tentang Kebijakan Akuntansi Pemerintah Provinsi Banten" yang disajikan di dalam Pergub No. 68 tahun 2016. Hal ini berdampak pada proses pemahaman atas penyusunan, penyajian dan pengungkapan pada LKPD tahun anggaran 2016 dapat dianalisa untuk dibandingkan dengan LKPD sebelum direviu yang telah disusun oleh Dinas Pengelola Pendapatan dan Keuangan Daerah (DPPKD).

Kedua, Pemahaman atas Sistem Pengendalian
Intern. Proses pemahaman atas SPI sesuai dengan Peraturan Menteri Dalam Negeri Nomor 4 Tahun 2008 tentang Pedoman Pelaksanaan Reviu LKPD terdiri atas memahami sistem dan prosedur pengelolaan keuangan daerah, melakukan observasi dan/atau wawancara dengan pihak terkait di setiap prosedur yang ada, melakukan analisis atas resiko yang telah diidentifikasi pada sebuah kesimpulan tentang kemungkinan terjadinya salah saji yang material dalam penyusunan laporan keuangan dan melakukan analisis atas resiko yang telah diidentifikasi pada sebuah kesimpulan tentang arah pelaksanaan reviu. Keseluruhan tahapan proses pemahaman SPI tersebut "telah dapat dilaksanakan sepenuhnya" oleh Inspektorat Provinsi Banten.

\subsubsection{Pelaksanaan}

Sesuai dengan Peraturan Menteri Dalam Negeri Nomor 4 Tahun 2008 tentang Pedoman Pelaksanaan Reviu LKPD, pelaksanaan reviu dilaksanakan oleh tim secara paralel dengan proses penyusunan LKPD. Reviu tersebut dilaksanakan paling lambat 2 (dua) bulan setelah tahun anggaran berakhir. Kegiatan-kegiatan dalam proses pelaksanaan tersebut meliputi penelusuran angka, permintaan keterangan dan prosedur analitis. Proses pelaksanaan "reviu oleh Inspektorat terhadap LKPD Tahun Anggaran 2016 dilaksanakan pada bulan Maret 2017". Hal ini tidak sesuai dengan Pedoman Pelaksanaan Reviu yang harus dilaksanakan paling lambat pada Bulan Februari tahun anggaran berikutnya. Keterlambatan tersebut dikarenakan pelaksanaan reviu LKPD Tahun Anggaran 2016 "tidak dilaksanakan secara paralel" dengan penyusunan LKPD. Reviu oleh Inspektorat Provinsi Banten dilaksanakan setelah Laporan Keuangan selesai disusun oleh DPPKD. LKPD yang telah selesai disusun oleh DPPKD tersebut selanjutnya dilakukan reviu oleh Inspektorat. Setelah reviu dilaksanakan, maka LKPD tersebut disesuaikan oleh DPPKD berdasarkan catatan-catatan pada Laporan hasil reviu. Proses selanjutnya adalah LKPD yang telah dilakukan perbaikan tersebut diserahkan kepada BPK RI untuk dilakukan pemeriksaan dan dilakukan pemberian Opini atas hasil pemeriksaan oleh BPK RI.

\subsubsection{Pelaporan}

Hasil pelaksanaan Reviu LKPD Tahun Anggaran 2016 telah disampaikan oleh Inspektur kepada Gubernur Provinsi Banten melalui Surat Nomor 700/261-Inspektorat/LHR/I/2017 tanggal 29 Maret 2017. Hasil reviu atas laporan keuangan pemerintah daerah (LKPD) provinsi Banten tahun 2016 
sebagai berikut:

a) Laporan Realisasi Anggaran (LRA)

Berdasarkan hasil reviu atas LRA Tahun Anggaran 2016, maka jumlah pendapatan sebesar Rp 8.656.395.495.445,00; jumlah belanja sebesar Rp 6.309.408.212.790,00; jumlah transfer sebesar Rp 2.616.405.229.424,00; dan jumlah pembiayaan netto sebesar Rp 828.574.818.588,00. LRA “tidak terdapat usulan koreksi", sehingga jumlah setelah reviu sama.

b) Laporan Perubahan Saldo Anggaran Lebih (LPSAL)

Jumlah Saldo Anggaran Lebih Akhir Tahun sebelum reviu sebesar Rp 559.156.871.819,00 dan berdasarkan hasil reviu "tidak terdapat usulan koreksi".

c) Neraca

Saldo awal akun-akun Neraca per 1 Januari 2016 telah sesuai dengan saldo akun-akun Neraca per 31 Desember 2015 menurut Laporan Hasil Pemeriksaan BPK RI atas LKPD Provinsi Banten Tahun 2015. Berdasarkan hasil reviu telah diusulkan jurnal koreksi karena terdapat selisih kenaikan jumlah aset pada persediaan sebesar Rp 172.338.600,00 dan usulan jurnal koreksi tersebut disetujui dan telah dikoreksi. Selain itu, terdapat juga usulan koreksi sebesar Rp 172.338.600,00 mengenai jumlah ekuitas dan telah dikoreksi. Untuk jumlah kewajiban, berdasarkan hasil reviu "tidak terdapat usulan koreksi".

d) Laporan Operasional (LO)

Bersarkan hasil reviu atas LO, "terdapat jurnal koreksi" untuk Jumlah pendapatan atas selisih sebesar Rp 5.976.329.500,00, jumlah beban atas selisih sebesar Rp 134.286. 532.406,56, jumlah beban luar biasa atas selisih sebesar Rp 79.784.904,00, dan jumlah surplus/defisit-LO dari $\mathrm{Rp}$ 371.844.362.681,95 menjadi Rp 243.454.374.909,39 koreksi tersebut terkait dengan pos Pendapatan-LO dan Beban sebagaimana diungkapkan sebelumnya.

e) Laporan Perubahan Ekuitas (LPE)

Berdasarkan hasil reviu "terdapat usulan koreksi" sebesar Rp 128.389.987.722,56 dan usulan tersebut telah disetujui dan dikoreksi.

f) Laporan Arus Kas (LAK)

Berdasarkan hasil reviu atas LAK untuk tahun yang berakhir sampai dengan 31 Desember 2016, maka "saldo akhir kas sebesar Rp 559.172.348.280,00" terdiri atas: saldo kas di kas daerah dan di bendahara penerimaan $\mathrm{Rp}$ 559.150.637.124,00, saldo kas di bendahara penerimaan $\mathrm{Rp} 21.711 .156,00$ dan saldo kas lainnya $\operatorname{Rp} 0,00$.

g) Catatan atas Laporan Keuangan (CaLK)

Secara umum CaLK "telah menyajikan informasi tentang transaksi dan kejadian material secara memadai", namun perlu penyesuaian terkait dengan koreksi sebagaimana disebutkan sebelumnya serta terdapat beberapa informasi penjelasan lainnya yang belum terdapat dalam CaLK.

h) Penilaian atas Sistem Pengendalian Intern

Sistem Pengendalian Intern yang terkait dengan penyusunan laporan keuangan secara umum memadai, namun "masih belum berjalan secara optimal" dalam hal-hal sebagai berikut: pengelolaan sistem aplikasi keuangan dan sistem aplikasi barang milik daerah masih belum berjalan secara baik sehingga menghambat dalam proses penyusunan laporan keuangan; penyusunan laporan keuangan SKPD pada umumnya belum dilakukan secara tertib; dan penatausahaan persediaan belum sepenuhnya dilakukan secara tertib.

i) Rekomendasi

Atas permasalahan sebagaimana tersebut diatas, direkomendasikan kepada Gubernur Banten agar memerintahkan secara tertulis kepada: kepala BPKD selaku Pejabat Pengelolaan Keuangan Daerah (PPKD) dan Bendahara Umum Daerah (BUD) untuk "selalu melakukan pembinaan" kepada para Kasubag Keuangan selaku PPK-SKPD, Bendahara Pengeluaran/Bendahara Pengeluaran Pembantu dan Bendahara Penerimaan; dan Kepala BPKD untuk "melakukan pembinaan" kepada Pengurus Barang dan Penyimpan Barang serta "melakukan penertiban pengelolaan persediaan".

\subsection{Korelasi Hasil Reviu Dengan Kualitas Akuntabilitas LKPD TA 2016}

LKPD yang telah dilakukan proses reviu oleh inspektorat selanjutnya dilakukan perbaikan oleh DPKD sesuai dengan saran hasil reviu. LKPD yang selesai diperbaiki kemudian disampaikan kepada BPK RI melalui kepala daerah. BPK RI telah melakukan pemeriksaan LKPD TA 2016 provinsi Banten dengan hasil pemeriksaan yang memuat opini "Wajar Tanpa Pengecualian" atau Unqualified Opinion. Berdasarkan beberapa catatan dari Laporan Hasil Pemeriksaan LKPD TA 2016 tersebut, diantaranya telah diungkap pada Laporan Hasil Reviu LKPD TA 2016 oleh Inspektorat berupa permasala- 
han pencatatan seperti pos persediaan dan pengungkapan pada CaLK terkait akun Kas, Sisa Lebih Pembayaran Anggaran (SILPA) dan Aset Tetap.

\section{KESIMPULAN DAN SARAN}

\subsection{Kesimpulan}

Berdasarkan hasil analisa prosedur dan dampak reviu inspektorat terhadap kualitas akuntabilitas laporan keuangan pemerintah daerah (LKPD) Provinsi Banten, peneliti dapat mengambil kesimpulan sebagai berikut. Pertama, prosedur perencanaan, pelaksanaan serta pelaporan reviu inspektorat terhadap kualitas akuntabilitas laporan keuangan pemerintah daerah provinsi Banten pada tahun 2016 sudah sesuai dengan pedoman pelaksanaan reviu berdasarkan Permendagri No.4 tahun 2008 tentang pedoman pelaksanaan reviu LKPD. Hal ini disebabkan karena adanya perencanaan reviu yang memadai, pelaksanaan reviu yang sesuai mendekati jadwal yang ditetapkan dan metode pelaksanaan reviu yang mengacu pada pedoman pelaksanaan reviu. Kedua, dampak Reviu Inspektorat dalam meningkatkan kualitas Akuntabilitas LKPD Provinsi Banten Tahun Anggaran 2016 dapat terealisasi. Hal ini dapat diketahui dengan opini hasil pemeriksaan BPK RI atas LKPD tahun anggaran 2016 sudah meningkat. Opini BPK RI atas LKPD Tahun Anggaran 2016 adalah wajar tanpa pengecualian (Unqualified Opinion). Akuntabilitas LKPD tersebut bukan tanggung jawab Inspektorat saja melainkan seluruh elemen di lingkungan Pemerintah Daerah namun Inspektorat juga memiliki peran penting dalam mewujudkan akuntabilitas keuangan daerah.

\subsection{Saran}

Berdasarkan hasil analisis, peneliti dapat memberikan dua saran perbaikan. Pertama, Pemerintah Daerah agar melakukan pendidikan dan pelatihan Peraturan Menteri Dalam Negeri Nomor Nomor 4 Tahun 2008 tentang Pedoman Pelaksanaan Reviu LKPD dan meningkatkan kemampuan pegawai Inspektorat melalui pelatihan-pelatihan dalam melaksanakan reviu LKPD. Kedua, agar Pemerintah Pusat dapat meningkatkan peran APIP, Pemerintah Daerah dapat berkoordinasi dengan Instansi Pembina APIP baik Inspektorat Jenderal Departemen Dalam Negeri maupun Badan Pengawasan Keuangan dan Pembangunan (BPKP).

\section{DAFTAR PUSTAKA}

Administrator. 2016. Profil atau sejarah singkat inspektorat Banten. https://inspektorat.bantenprov.go.id/id/read
/ sejarah-singkat.html

Badan Pemeriksa Keuangan Republik Indonesia. 2016. Laporan Hasil Pemeriksaan Dan Laporan Keuangan Pemerintah Daerah provinsi Banten Tahun Anggaran 2013-2015. Jakarta: Pusat Informasi dan Komunikasi BPK RI

Badan Pemeriksa Keuangan Republik Indonesia. 2017. Laporan Hasil Pemeriksaan Dan Laporan Keuangan Pemerintah Daerah provinsi Banten Tahun Anggaran 2016. Jakarta: Pusat Informasi dan Komunikasi BPK RI

Gani, William. dan Kristanto, Septian Bayu. 2013. "Pengaruh Dana Alokasi Umum Dan Khusus Terhadap Belanja Daerah Pada Kabupaten/Kota Di Pulau Sumatera". Jurnal Infestasi Vol. 9 No.2 : 115 - 122.

Haryadi, Anda Dwi. 2010. "Pengaruh reviu inspektorat dan nilai temuan pemeriksaan terhadap opini audit BPK". Jurnal Akuntansi dan Manajemen Vol. 5 No.2: 10 - 21.

Indriasih, D. 2014. "The Effect of Government Apparatus Competence and the Effectiveness of Government Internal Control Toward the Quality of Financial Reporting in Local Goverment". South East Asia Journal of Contemporary Business, Economics and Law Vol. 5 ISSN 2289-1560.

Kluvers, R. and Tippet, J. 2009. "The anatomy of accountability in local government". The Anatomy of Accountability Paper No. 146: 1-13.

Peraturan Menteri Dalam Negeri No.4 Tahun 2008 Tentang Pedoman Pelaksanaan Reviu Laporan Keuangan Pemerintah Daerah

Peraturan Pemerintah No.60 Tahun 2008 Tentang Sistem Pengendalian Intern Pemerintah (SPIP)

Peraturan Pemerintah Republik Indonesia No.71 Tahun 2010 Tentang Standar Akuntansi Pemerintahan

Peraturan Pemerintah No.12 Tahun 2017 Tentang Pembinaan dan Pengawasan Penyelenggaraan Pemerintah Daerah

Rahmi, Novrieza. 2017. APIP Sang Pengawas, Bukan Bagian Mata Rantai Korupsi!. Hukum Online. http://www.hukumonline.com/berita/baca/1 t5988456348404/apip-sang-pengawas--bukanbagian-mata-rantai-korupsi

Undang-undang No.1 Tahun 2004 Tentang Perbendaharaan Negara

Widyarini, K. dan Ratnadi, N. 2016. "Pengaruh prosedur, pendidikan, tekanan waktu, dan angaran reviu pada kualitas reviu laporan keuangan pemerintah daerah". E-Jurnal Ekonomi dan Bisnis Universitas Udayana 5.3 ISSN : 2337-309 